\title{
Organization of healthcare and assistance to the elderly indigenous population: synergies and particularities of the professional context*
}

\author{
ORGANIZAÇÃO DO SERVIÇO DE SAÚDE E CUIDADO AO IDOSO INDÍGENA: \\ SINERGIAS E SINGULARIDADES DO CONTEXTO PROFISSIONAL
}

\author{
ORGANIZACIÓN DEL SERVICIO DE SALUD Y LAATENCIÓN A LOS ADULTOS MAYORES \\ INDÍGENAS: SINERGIAS Y SINGULARIDADES DEL CONTEXTO PROFESIONAL
}

\author{
Leidyani Karina Rissardo", Lígia Carreira²
}

\begin{abstract}
This study aimed to describe the effects of the organization of primary healthcare on the assistance provided to the elderly Kaingang population, according to the perception of health professionals that work in this area. It is a qualitative and descriptive study, supported by ethnography methodological references, and was conducted with ten healthcare professionals that work in Faxinal, an indigenous territory in the state of Paraná, in Brazil. Data was collected from November 2010 to February 2012 through participant observation and interviews. The results revealed that health professionals strive to meet the health needs of the elderly Kaingang people; however, there are negative effects that hinder the professional care, especially limited human resources, lack of training and material resources, heavy workload and high turnover rates. This study highlights the need to improve work conditions in order to provide better healthcare.
\end{abstract}

\section{RESUMO}

Objetivou-se descrever os reflexos da organização do serviço de atenção primária à saúde indígena para o cuidado ao idoso Kaingang na percepção de profissionais da saúde que atuam na área. Estudo qualitativo, descritivo, apoiado no referencial metodológico da etnografia, realizado com dez profissionais de saúde que trabalham na terra indígena Faxinal, Paraná, Brasil. Os dados foram coletados entre novembro de 2010 e fevereiro de 2012 por meio de observação participante e entrevistas. Os resultados revelaram que os profissionais de saúde esforçam-se para atender as necessidades de saúde dos idosos Kaingang; no entanto, existem reflexos negativos na assistência em saúde ao idoso que dificultam o cuidado profissional, principalmente a limitação de recursos humanos, a falta de capacitação e recursos materiais, a sobrecarga de trabalho e a rotatividade dos profissionais. Evidencia-se a necessidade da melhoria das condições de trabalho para a qualificação dos cuidados prestados.

\section{RESUMEN}

Este estudio tuvo como objetivo describir los efectos de la organización del servicio de atención primaria de la salud indígena para la atención de los adultos mayores Kaingang, bajo la percepción de los profesionales de salud que trabajan en la región. Estudio cualitativo, descriptivo, apoyado en el referencial metodológico de la etnografía, llevado a cabo con diez profesionales de salud que trabajan en la tierra indígena de Faxinal, Paraná, Brasil. Los datos fueron recolectados desde noviembre del 2010 hasta febrero del 2012 a través de la observación del participante y las entrevistas. Los resultados revelaron que los profesionales de salud se esfuerzan por satisfacer las necesidades de salud de los adultos mayores Kaingang; sin embargo, existen efectos negativos en la atención de la salud a las personas de la tercera edad que dificultan la atención profesional, principalmente, la limitación de recursos humanos, la falta de capacitación y de recursos materiales, la sobrecarga de trabajo y la rotación de estos profesionales. Este estudio pone en relieve la necesidad de mejorar las condiciones de trabajo para la calificación de la atención prestada.

\section{DESCRIPTORES}

Servicios de Salud del Indígena

Anciano

Salud Indígena

Enfermería transcultural

Enfermería geriátrica
Transcultural nursing

Geriatric nursing

\author{
Serviços de Saúde do Indígena \\ Saúde Indígena \\ Enfermagem transcultural \\ Enfermagem geriátrica
}




\section{INTRODUCTION}

The Brazilian Constitution of 1988 outlined the political foundations on which the relationships between indigenous peoples and the Brazilian state should be based, being the fundamental assumption the appreciation of indigenous peoples, their social organization, costumes, languages, beliefs and traditions... (Art. 231). This is reflected in the Brazilian Indigenous Peoples Healthcare Policy (PNASPI) and incorporated in the documents of the Special Secretariat of Indigenous Health (SESAI), an agency of the Ministry of Health in charge of the management of the Indigenous Healthcare Subsystem and the Special Indigenous Health District (DSEI), which highlight the need to provide special care that concurrently ensures universal access to health services and respect and appreciation to the traditional medicine $e^{(1-3)}$.

The primary healthcare (PHC; in Portuguese APS) is the basis for the indigenous healthcare model, with the inclusion of healthcare units in indigenous territories and a team of indigenous healthcare multidisciplinary professionals (EMSI), aimed at providing ongoing and planned assistance, according to the guidelines of the Family Health Strategy provided by the Ministry of Health ${ }^{(2-3)}$.

Although the indigenous healthcare model has presented progress over the years, it is a consensus among some authors that the implementation of policies in the context of indigenous health is limited ${ }^{(1,4-5)}$. There are problems such as the lack of an efficient information system, the difficulty of connecting to the Brazilian Unified Health System (SUS) and the lack of a qualified staff to work in an intercultural context, which contributes to a high turnover of professionals ${ }^{(1,4-5)}$. These problems are particularly relevant with regards to indigenous healthcare.

Aging involves both the natural process of gradual reduction of the individuals' functional capacity, defined as senescence, and situations that may trigger pathologies requiring quality assistance, which are defined as senility. Given the existence of these two possibilities for the elderly regarding their general condition, it is argued that aging effects can be minimized by proper healthcare ${ }^{(6)}$.

Given the importance of this issue, this study seeks to understand the relationship between the organization of the service and the healthcare professional practices for elderly indigenous people. This study aimed to describe the effects of the PHC service organization on the healthcare practices for the elderly Kaingang population, according to the perception of professionals working in this area.

\section{METHOD}

It is a qualitative and descriptive study, based on ethnography. Ethnography is a methodology in the field of interpretive anthropology with the primary purpose to study a society or a culture in its entirety, understanding it from within, i.e., trying to understand what its individuals feel ${ }^{(7-8)}$.

The study was conducted in the Faxinal indigenous territory (TIF), located in the city of Cândido de Abreu, in the state of Paraná, Brazil, where about 600 indigenous people live, mostly from the Kaingang ethnic group, of which 30 are elderly ${ }^{(9-10)}$. The Faxinal Basic Health Unit (UBS) was the main place where the study took place. Founded on April 26, 2003, this unit is in the center of the TIF, which allows constant circulation of people around it and contributes to a very broad view, reaching an expanded are in the village.

Ten health professionals working in the PHC of the TIF were subject to the study, specifically: a nurse, a doctor, a dentist, a nursing technician, nursing assistant, four indigenous healthcare agents (AIS) and a healthcare driver. All of them were included in the study after accepting to participate in the research and confirming that they have worked for at least three months in the TIF.

Data collection occurred from November 2010 to February 2012, through eight trips to the TIF. In each of them, researchers remained on site for a week. Participant observation and interviews were used as data collection techniques, guided by the question: What are the effects of the organization of service on the professional healthcare for the elderly Kaingang population?

Three instruments were elaborated to support data collection: the first one discussed about situations that should have been observed on site; the second one sought to characterize the study setting and location, and the last one was the interview. Another decision was to interview four key information sources, whose function was to contribute to the understanding of the findings, deepening the knowledge about the indigenous culture and worldview, as well as assist in approach strategies during data collection. The eligibility criteria for key information sources were to know the Kaingang culture and have a long experience in the TIF.

Data analysis was performed using the Ethnonursing proposed by Madeleine Leininger in her Culture Care Diversity and Universality theory. It consists of in-depth data reading in search of convergences and divergences, statements and behaviors, which are categorized according to the identification of recurring patterns. The manipulation of findings allows elaborating inferences that are confirmed while collecting data from the respondents and key information sources, and from this confirmation, it is possible to abstract categories and theoretical formulations ${ }^{(8)}$.

The study was conducted in accordance with the requirements of Resolution 422/92012, of the Brazilian National Health Council, and the project was approved by the National Research Ethics Committee - CONEP, as of Opinion No. 760/2010. To protect the identity of the 
interviewed professionals, they were identified by the letter $\mathrm{P}$ followed by an Arabic numeral indicating the order of the interviews.

\section{RESULTS}

\section{Meeting health professionals}

From the ten health professionals, five were male, four were in the 20-29 age group, two were 30-39 years old, two were 40-49 and two were 50 years and over. With regards to their marital status, five were married or lived with a partner and five had children. Regarding their education, one had incomplete primary education, two had complete primary education, four had finished high school and three had completed their higher education. As for the time of their professional relationship with the EMSI, four had worked there from five to 12 months, four from one to seven years and two had worked in the TIF for over seven years. Only three had more than one job: two worked concurrently in hospitals and one in a private clinic. Regarding their professional experience, three said that this was their first job, four had professional experience, but in hospitals and with non-indigenous population, and only two professionals had worked with other indigenous peoples.

Becoming acquainted with the work of these health professionals with the elderly in the TIF allowed the construction of a theme category: Daily life and health: (in) consistencies in the organization of service for professional healthcare to the elderly Kaingang population, presented below.

\section{Daily life and health: (in) consistencies in the organization of service for professional healthcare to the elderly Kaingang population}

The healthcare provided to the elderly Kaingang population in TIF requires an organization, as shown in Figure 1.

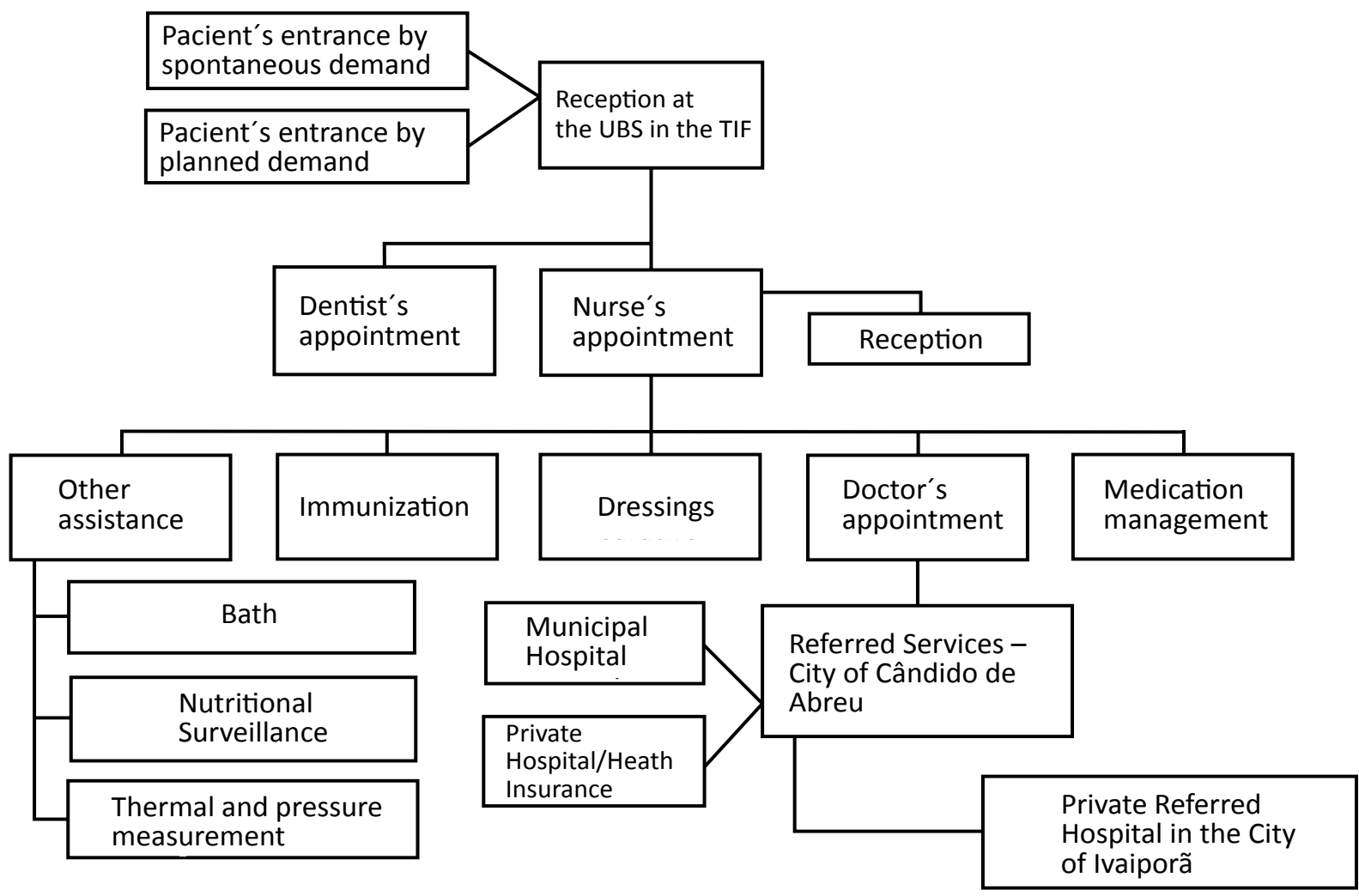

Figure 1 - Diagram of PHC assistance to the elderly Kaingang population in the Faxinal indigenous territory, in the state of Paraná, Brazil, 2012.

The dental care provided to the elderly at the Basic Health Unit (UBS) has exclusive scheduling, with screening and classification by order of priority, separate from other healthcare sectors. This organization occurs either through spontaneous demand, in which there is assistance to individuals with problems, or though planned demand, in which clinical conditions of the oral health of the elderly are monitored.
It was observed that the afternoon was reserved for planned visits, which were scheduled as appointments for each patient. However, regarding the elderly patients, the afternoon was usually reserved for a single appointment, given the complexity of the oral health cases of the elderly in the TIF, which requires a long period of time. Nevertheless, besides the special attention required by the elderly cases, it was observed the lack of human resources in the 
UBS, which made the dentist work without the help of another professional.

When the elderly looks for dental care, that's because their oral health condition is already extreme. They are very afraid of the equipment used for assistance, so they avoid scheduling visits. Therefore, when they look for the UBS assistance, their teeth conditions are already precarious, requiring extraction or other procedures that also take a long time. This is a difficult situation because the dentist doesn't have an assistant to help him. Sometimes the indigenous health agent (AIS) or someone in nursing helps him, but it is not the same thing; there is a lack of human resources, there is a lack of dental hygienists (THD) (P3).

When faced with a condition that requires assistance other than dental care, the elderly is received by the nursing staff, which analyses the case and sets the necessary procedure. The nursing reception and appointment in the TIF are synergistic, as the reception is performed together with the appointment. Although health professionals recognize that receiving the elderly has a positive impact on the progress and outcome of the assistance, there are restraints in this process, which generate dissatisfaction to the professionals regarding their conduct in assisting the elderly. This dissatisfaction refers mainly to the limitations in communication, which highlights the need of professional training in the TIF related to the knowledge of the Kaingang language to better receive the elderly population, as most of them communicate exclusively in their mother tongue.

Most of the elderly in the village speak Kaingang, and I don't know many words in this language. This is a restraint when we assist them because I feel I don't receive them as I should. I would like to speak Kaingang really well and understand what they are saying (...) (P1).

When analyzing this issue, one can see that the language is the first restraint of many others, as well as the relationship difficulties between the professionals and the elderly Kaingang people. Limitations related to the elderly's costumes, values and lifestyle can involve knowledge absorption by the professionals, a fact that limits the health assistance to this population, as without this kind of knowledge, they cannot provide special care, i.e. culturally-adapted care.

It was also observed that the UBS physical structure limits the quality of care. The UBS has twelve rooms, as follows: reception desk, dentist's office, doctor's office, vaccination room, room for medication management and nebulization, a pharmacy for dispensing and stocking medicines, kitchen, administrative office, dressing room, two bathrooms and a laundry room, and they need to be improved, especially when it comes to space expansion. This need is even more evident when the professionals need a private space to talk to the indigenous elderly people.
When some of the elderly people come to the UBS, I like to talk to them in private, especially with those that have a delicate topic to be approached. I'm saying this because here in the indigenous territory there are many cases of violence against the elderly and, as I have some intimacy with some of them, I can talk to them about it. But when the dentist and the doctor are using the rooms, there is no proper place when we can talk in private here at the UBS (...) (P1).

It highlights the importance of having a proper place to provide quality service to the elderly indigenous especially because, if they mention the violence issue in places where there are individuals other than the professional, the patient will go against the principles that govern the humanization and ethics.

Moreover, the issue of violence against the elderly requires more than only proper physical structure to receive patients. Health professionals emphasize the violence as a social problem related to the elderly, suggesting the need to expand the team, including professionals from other areas to work with a more comprehensive approach, such as social workers, psychologists and professionals of related areas. Understanding the importance of professionals to work more specifically on the social aspect of the Kaingang elderly means looking for comprehensive care, with a worldview that goes beyond the individual's health-disease process.

The issue of mistreatment of the elderly is an increasingly serious problem here in the indigenous territory and it happens especially between spouses. This also happens because alcohol consumption is high among the elderly and, after some drinks, violence always comes up (...) I think that if we had a social worker in our team, we could work better on these social aspects that involve the elderly (...) (P4).

I feel the need of having a social worker here in the village because, if we had social support, and this kind of professional working next to us, most of the elderly-related problems could be solved (P2).

However, in addition to the aforementioned limitations, the TIF professionals are faced with a heavy workload, which makes them resort to an assistance more focused on the elderly's complaint, the symptoms, as well as drugs prescription and dispensing, which reflects a curative logic.

I know we don't meet all health needs of the elderly, especially because their needs go beyond their condition and the drug treatment. But I don't have enough time to elaborate a program that aims at special care for them. I fill out fourteen reports per month and each of them relates to actions that take a long time. It refers to pregnant women, children, nutritional surveillance, STD (...) I see myself surrounded by paper and I don't have time to provide comprehensive care to the elderly. I only see the elderly when they come here or somebody calls us. We do what we can. (P2). 
The heavy workload of the professionals is increased by paperwork related to the services provided, with reports to be filled out and the lack of professionals to help in this process, for example, typing and send these documents. This fact is aggravated by insufficient material resources to speed bureaucratic procedures, such as lack of internet and telephone services (fixed or mobile), which delays the process of sending reports and even the communication with higher service providers. In addition to this, at the UBS there is only one computer and an old typewriter, which requires ongoing maintenance.

Other restraints mentioned are the lack of human resources in health assistance and the administrative area, inappropriate physical structure and lack of material resources, which result in heavy workload, in addition to delaying and complicating the provision of service to the population. The professionals also listed constraints in providing home care services to the elderly. In most cases, home visits were made by the AIS, while the other professionals only visited bedridden people or those that were unable to go to the UBS and needed some medical or nursing intervention:

\begin{abstract}
If we said we are able to visit the elderly every week, we would be lying. We have many things to do here at the UBS, we don't have any time left to plan this (...) When the elderly need nursing procedures, the nurse visits them. When they need medical care, the doctor goes there. But, it's something like this: we only go if the elderly really needs it. The AIS have more contact with the elderly, but they also do what they can. When they hear an elderly is feeling sick, they go ckeck on him/her and, if it's true, they get back to us, informing the case. We don't have an established routine to visit the elderly; there is no ongoing care program (P8).
\end{abstract}

Aware that structural and organizational barriers impair the care provided to the Kaingang elderly, the professionals try to reduce these obstacles strengthening teamwork at the UBS.

When the elderly come to the UBS, we have to check on everything, not a particular issue. For example, during the appointment with the dentist, if we notice a problem other than teething, we communicate it to the nursing staff, so that they can contact the patient and give him orientation.

Establishing internal bonds in the work process is critical to providing comprehensive care; however, when it comes to indigenous health service, there is not always this complicity among the professionals, because their turnover rates are high and those recently hired are most of times not able to be part of the team. It is important to note that the turnover is due to the influence of the tribal chief in hiring health professionals, as the chief is an authority in the Kaingang group and is responsible for organizing the community and creating moral codes within the indigenous territory, including the UBS. During the on-site stay, there were three changes of chief, and the last one resulted in changes in the health team.
When the tribal chief came here, he said: I don't want that, that, that and that employee I was surprised because it meant four less employees in the team and this is a difficult situation because they were already familiar with the work routine (...) I believe the turnover impacts a lot more the elderly healthcare than other individuals here because the elderly is reserved, resists to receive treatment from professionals they don't feel comfortable with, who they don't trust yet (P2).

The role of the tribal chief emerges as a peculiar aspect in the organization of service, because it brings a political dimension, with strong intervention in healthcare. It is a peculiarity of the indigenous world that impacts health services and the professionals tend to be resistant, because there is a cultural clash. This fact becomes a point of conflict between the service logic and the grounds that govern the indigenous political power, which should be noted within the indigenous health policy.

Concerning access of the elderly to healthcare, it was observed that some of them have difficulty in going to the UBS, due to the distance from their homes to the village center, where the unit is located. The distance is a restraint, but does not prevent access to services, since the UBS has exclusive transportation to meet their needs. The vehicle is used to transport the elderly around the village, for example, it takes them to the UBS, especially when they need to be taken to other SUS related services.

We need to be alert about the elderly being able to receive healthcare. Sometimes, when it rains, they're not able to come to the UBS because of the unpaved streets and the limitation that some of them have to walk. When this happens, I always ask the driver to go get them (...) Having a vehicle and a driver available full time is something that helps us a lot. The car is here all the time; if the doctor refers them to the city, transportation is immediately available to take them (P2).

At the same time the transportation seems to be a facilitator, the professionals mentioned the lack of structure in health services outside the TIF, which hinders the care to the elderly in these places. This fact has a negative impact on healthcare in the TIF, as the elderly, when learning about the difficulties in the support network outside the TIF, are resistant to the use of these services, which impacts the healthcare services provided to this population.

\begin{abstract}
When we work with an indigenous elderly population, it's important for us to have a solid referenced network, not only at the UBS, but in other related services because, for the elderly, any obstacle is a reason to quit treatment. I think we should have a place for the elderly to stay when they have to go to SUS related services; a support house where they can stay when they have an appointment (P6).
\end{abstract}

This limitation of the infrastructure of health services outside the TIF also occurs in cases where the elderly have to remain in hospitals, because, according to the health professionals in the TIF, these places receive both
Organization of healthcare and assistance to the elderly indigenous population: synergies and particularities of the professional context Rissardo LK, Carreira L 
non-indigenous and indigenous people in the same space. Interacting with people they do not know embarrass the Kaingang elderly, making later referrals even harder.

\section{DISCUSSION}

The multidisciplinary indigenous healthcare team provides services to the Family Health Strategy (ESF) ${ }^{(2)}$. Each professional has a specialty and function, performing a couple of actions separately, but constantly and continuously looking for connections between their assistance and that of others. The teams need to seek integrality in their actions, rather than only producing a biomedical care model in their work process ${ }^{(11)}$.

It is evident that health professionals in this study recognize the importance of a comprehensive and special care to the Kaingang elderly. However, when faced with mishaps in the organization of the service, they limit themselves to providing individualized and healing care. One of the major obstacles to the effective consolidation of the EMSI is the lack of professionals prepared to perform new tasks required by the indigenous healthcare model ${ }^{(12)}$.

A limited staff affects the viability of care for the elderly indigenous, as these individuals have a series of health complications, which requires professionals who are actually trained in their specialties and are really able to provide solutions, proposing special healthcare.

The lack of human resources is also evident in the family healthcare teams who work with non-indigenous elderly people, as shown in a study with 17 health professionals from two FHS teams in Santos. The lack of human resources has proved to be a restraint to comprehensive healthcare for the elderly in the city, especially with regards to social support, as the family health team does not have professionals working on social aspects ${ }^{(13)}$.

This fact is similar to this study's results, in which the social vulnerability of the Kaingang elderly to violence is evident. Faced with the challenge of insufficient human resources in the social axis, healthcare professionals need to use their creativity to elaborate strategies to overcome the limitations in the organization of service. A similar aspect would be the intersectoriality in the Kaingang elderly care, seeking support in the social bodies of the community, such as partnerships with churches, schools and leaders in the TIF, with the intent to mobilize the population to promote health assistance and care to the Kaingang elderly.

A research conducted in the city of Uberaba, with 12 nurses, revealed that intersectoriality can contribute a lot to the elderly healthcare because, even with insufficient human resources dedicated especially to elderly-related social problems, the social bodies of the city could solve some of these problems, reducing the mishaps faced by the elderly that look for assistance ${ }^{(14)}$. Although the problems have been minimized, the study also shows the lack of training for professionals working in this area(14). An insufficient health team in numbers and training affects negatively the care provided.

In the case of the indigenous elderly, trained professionals are even more important to the development of healthcare because, in addition to the services techniques and capacities, the care provided to this elderly population requires a transcultural approach, with knowledge of cultural aspects, especially those related to their language ${ }^{(3)}$, since the difficulty of communication between the professional and the elderly hinders health services.

Other studies also indicate language as a limiting factor in the process of care to indigenous peoples, since this barrier generates stereotypes, given that the inefficiency of the services resulting from language barriers limits the contact with healers and the traditional therapeutic practices of the community, as well as making difficult the professionals' understanding of this population's lifestyle $\mathrm{e}^{(12,15-16)}$, which hinders the quality of the services provided.

Teamwork can contribute to the improvement of special healthcare to the indigenous elderly because in the EMSI there are AIS, professionals that are essential for executing and articulating traditional care to the population, since they are part of the cultural traditions and know the costumes, values, myths and rites of the assisted population. One of the criteria for admission in this position is to be indigenous and live in the village where they work ${ }^{(1)}$.

With the contribution of the AIS, professionals can have a better insight in what concerns the health of the Kaingang elderly, since the routine of the team is marked by heavy workload, mainly due to existing limitations and paperwork at the UBS, which limits services interconnected with home care.

Authors state ${ }^{(14,17)}$ that it is possible to give paperwork tasks to other professionals, but, when the actions are educational and related to care, they cannot be attributed to a member who is not trained, which is the most aggravating aspect in the heavy workload of team members who have to perform paperwork having, at the same time, insufficiency of professionals to provide care to the population. Rotation among professionals for performing paperwork could contribute to the nurse, doctor and other professionals qualified for guidance and intervention in healthcare, since it would allow them to expand the scope of care, with more time to plan actions and home visits ${ }^{(18-19)}$.

Teamwork is the doctrinal and organizational cornerstone of the care-based model, allowing an interdisciplinary approach in dealing with complex conditions and determinants of the health-disease of the elderly assisted by the $\mathrm{ESF}^{(6)}$. It was observed, however, that not always is teamwork evident in the TIF, since the influence of the local leadership leads to turnovers, and the most recent professional are unable to engage in teamwork. 
A study conducted in the indigenous territories of Xapecó and Laklanõ, in the state of Santa Catarina, Brazil, presents similar results, finding that the high turnover rates result from socio-political arrangements of the organization of internal political dynamics in the villages and from the tribal chief authority for the permanence of professionals, especially the AIS ${ }^{(20)}$.

The participation of the tribal chief in the work process of health professionals should be taken into consideration as a way of strengthening popular participation. It was observed, however, that professionals still do not understand the synergy between their actions and the political role of the tribal chief as a community participation, which can certainly contribute to the consolidation of the care model in the ESF and to the culturally-adapted care.

The knowledge of the tribal chief of service needs and the effects of turnovers on the Kaingang elderly care should be a topic for discussion, so that there is a partnership with the local leaders and the decisions are shaped by service needs not by personal convictions and internal divergences in the Kaingang community. The partnership with the tribal chief favorable to the health service can become a positive proposal, since this individual influences both the access to professional care and its link and retention in the healthcare process.

With regards to access to services, it was observed that the available transportation is favorable for the Kaingang elderly care. SESA, an agency in charge of indigenous health in Brazil, states that the means of transportation, both for health professionals and for the referral of indigenous people, may be in good condition for use and have drivers available when necessary ${ }^{(2-3)}$. This fact is extremely important because the elderly need greater agility in the health system, since the aging process brings, as a consequence, less willingness to seek health services and move to different care levels.

In addition to this, any difficulty becomes a barrier that stops or disrupts the continuity of healthcare for this individual $^{(13)}$. This limitation of the elderly to health services was evident in this study because, although the organizational structure of the subsystem of the Indigenous Healthcare included the homes of Indigenous Healthcare - CASAI ${ }^{(3)}$, it was observed that when the elderly were referred to health services outside the TIF, there was no

\section{REFERENCES}

1. Diehl EE, Langdon EJ, Dias-Scopel RP. Contribuição dos agentes indígenas de saúde na atenção diferenciada à saúde dos povos indígenas brasileiros. Cad Saúde Pública. 2012;28(5): 819-31.

2. Garnelo L, Pontes AL. Saúde indígena: uma introdução ao tema. Brasília: MEC/SECADI; 2012. proper place where they could stay until they were released, which causes resistance in these individuals to move to referenced services.

Given these obstacles, one of the possibilities to overcome the difficulties in providing healthcare to the Kaingang elderly is if the team shows higher authorities the importance of having good conditions for developing a good work, especially home care and actions aimed at the participation of indigenous people in the process of the Kaingang elderly care.

\section{CONCLUSION}

This study has enabled to describe the effects of the organization of service in the Kaingang elderly care in the TIF. It identified a variety of conditions that hinder the care of the elderly, such as: limited human resources, lack of professional training, lack of proper physical structure that meets the needs of the elderly, limitation of professionals to take care of elderly-related social aspects, paperwork - which ends up taking a lot of time and overloading daily work -, lack of material resources and turnover of professionals due to the influence of the tribal chief in the organization of the health service in the TIF.

On the other side, it showed that professionals try to work in team in order to minimize these restraints. It is worth saying that having a vehicle with a driver available full time at the UBS was considered by the professionals a positive aspect in the service organization.

Even evidencing the need to adapt the working conditions of professionals for elderly healthcare, it is essential to adopt strategies that reduce the negative impacts to the Kaingang elderly care in order to provide active and healthy aging for the indigenous elderly.

The nursing team, especially the nurse who has as part of her duties the management of the health service, has an important role to establish strategies and provide better healthcare for the elderly.

The results of this study may contribute to the creation of strategies that aim to improve health services and to (re)consider the work process of these professionals in the pursuit of knowledge, professional satisfaction and quality care provided to elderly indigenous.
3. Brasil. Ministério da Saúde; Fundação Nacional de Saúde. Política Nacional de Atenção à Saúde dos Povos Indígenas [Internet]. Brasília; 2002 [citado 2013 fev. 08]. Disponível em: http://bvsms.saude.gov.br/bvs/publicacoes/politica_saude_ indigena.pdf
Organization of healthcare and assistance to the elderly indigenous population: synergies and particularities of the professional context Rissardo LK, Carreira L 
4. Diehl EE, Grassi F. Uso de medicamentos em uma aldeia Guaraní do litoral de Santa Catarina, Brasil. Cad Saúde Pública. 2010;26(8):1549-60.

5. Langdon EJ, Diehl EE. Participação e autonomia nos espaços interculturais de Saúde Indígena: reflexões a partir do sul do Brasil. Saúde Soc. 2007;16(2):19-36.

6. Barros TB, Maia ER, Pagliuca LMF. Facilidades e dificuldades na assistência ao idoso na estratégia ao idoso na estratégia de saúde da família. Rev RENE. 2011;2(4):732-41.

7. Malinowski B. Objetivo, método e alcance desta pesquisa. In: Zaluar A. Desvendando máscaras sociais. Rio de Janeiro: Francisco Alves; 1990. p. 39-61.

8. Leininger M, Mcfarland MR. Culture care diversity and universality: a worldwide nursing theory. 2nd ed. New York: Jones and Bartlett; 2006.

9. Mota LT. As guerras dos índios Kaingang: a história épica dos índios Kaingang no Paraná (1769-1924). 2a ed. Maringá: EDUEM; 2009. p.45-66.

10. Instituto Brasileiro de Geografia e Estatística (IBGE). Censo demográfico 2010: características gerais dos indígenas [Internet]. Rio de Janeiro; 2010 [citado 2012 nov. 08]. Disponível em: http://www.sidra.ibge.gov.br/bda/tabela/listabl. asp?c $=3452 \& z=c d \& o=10$

11. Costa CR, Fracolli LA. O processo de enfermagem em atenção primária à saúde. In: Santos AS, Miranda SMRC, organizadoras. A enfermagem na gestão em atenção primária à saúde. Barueri: Manole; 2007. p. 147-65.

12. Novo MP. Política e intermedicalidade no Alto Xingu: do modelo à prática de atenção à saúde indígena. Cad Saúde Pública. 2011;27(7):1362-70.

13. Costa MFBNA, Ciosak SI. Comprehensive health care of the elderly in the Family Health Program: vision of health professionals. Rev Esc Enferm USP [Internet]. 2010 [cited 2013 Feb 20];44(2):437-44. Available from: http://www.scielo.br/ pdf/reeusp/v44n2/en_28.pdf
14. Oliveira JCA, Tavares DMS. Elderly attention to Health Strategy in the Family: action of nurses. Rev Esc Enferm USP [Internet]. 2010 [cited 2013 Feb 20];44(3):774-81. Available from: http://www.scielo.br/pdf/reeusp/v44n3/en_32.pdf

15. Alarcón AMM, Astudillo P, Barrios S, Rivas E. Política de salud intercultural: perspectiva de usuarios mapuches y equipos de salud en la IX región, Chile. Rev Méd Chile. 2004;132 (9):1109-14. Available from: http://www.scielo.cl/pdf/rmc/ v132n9/art13.pdf

16. McBain-Rigg KE, Veitch C. Cultural barriers to health care for Aboriginal and Torres Strait Islanders in Mount Isa. Aust J Rural Health. 2011;19 (2):70-4.

17. Marcon SS, Lopes MCL, Lopes MB. Facilities and difficulties observed by nurses in assisting families. Online Braz J Nurs [Internet]. 2008 [cited 2013 Feb 15];7(1). Available from: http://www.objnursing.uff.br/index.php/nursing/article/ view/j.1676-4285.2008.1224

18. Roecker S, Budó MLD, Marcon SS. The educational work of nurses in the Family Health Strategy: difficulties and perspectives on change. Rev Esc Enferm USP [Internet]. 2012 [cited 2012 Nov 08];46(3):641-9. Available from: http://www. scielo.br/pdf/reeusp/v46n3/en_16.pdf

19. Marin MJS, Santana FHS, Maracvick MYAD. Nurses' perception regarding the implementation of computer-based clinical nursing documentation. Rev Esc Enferm USP [Internet]. 2012 [cited 2013 Feb 20];46(1):103-10. Available from: http://www.scielo.br/pdf/reeusp/v46n1/en_v46n1a24.pdf

20. Langdon EJ, Diehl EE, Wiik FB, Dias-Scopel RP. A participação dos Agentes Indígenas de Saúde nos serviços de atenção à saúde: a experiência em Santa Catarina, Brasil. Cad. Saúde Pública. 2006;22(12):2637-46.

\section{Acknowledgement}

This study was conducted through the research project "The knowledge and practices of healthcare to in the Kaingang elderly in the Indigenous Territory of Faxinal-Paraná", funded by the Araucaria Foundation through the SUS Research Program: Management shared with Saúde PPSUS - 2008/2009 - Agreement No. 179/2010. 